\title{
Caffeine and human DNA metabolism: the magic and the mystery
}

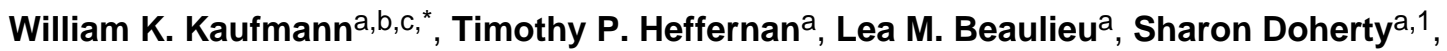 \\ Alexandra R. Frank ${ }^{a}$, Yingchun Zhou ${ }^{a}$, Miriam F. Bryant ${ }^{a}$, Tong Zhou ${ }^{a}$, Douglas D. Luche ${ }^{a}$, \\ Nana Nikolaishvili-Feinberg ${ }^{a}$, Dennis A. Simpson ${ }^{a}$, and Marila Cordeiro-Stone ${ }^{a, b, c}$ \\ aDepartment of Pathology and Laboratory Medicine, University of North Carolina at Chapel Hill, \\ Chapel Hill, NC 27599, USA \\ bLineberger Comprehensive Cancer Center, University of North Carolina at Chapel Hill, \\ CB\#7295, Chapel Hill, NC 27599, USA \\ ${ }^{\circ}$ Center for Environmental Health and Susceptibility, University of North Carolina at Chapel Hill, \\ Chapel Hill, NC 27599, USA
}

\begin{abstract}
The ability of caffeine to reverse cell cycle checkpoint function and enhance genotoxicity after DNA damage was examined in telomerase-expressing human fibroblasts. Caffeine reversed the ATM-dependent $\mathrm{S}$ and $\mathrm{G} 2$ checkpoint responses to DNA damage induced by ionizing radiation (IR), as well as the ATR- and Chk1-dependent S checkpoint response to ultraviolet radiation (UVC). Remarkably, under conditions in which IR-induced G2 delay was reversed by caffeine, IR-induced G1 arrest was not. Incubation in caffeine did not increase the percentage of cells entering the S phase 6-8 h after irradiation; ATM-dependent phosphorylation of p53 and transactivation of $\mathrm{p} 21^{\mathrm{Cip} 1 / \mathrm{Waf} 1}$ post-IR were resistant to caffeine. Caffeine alone induced a concentration- and time-dependent inhibition of DNA synthesis. It inhibited the entry of human fibroblasts into S phase by 70-80\% regardless of the presence or absence of wildtype ATM or p53. Caffeine also enhanced the inhibition of cell proliferation induced by UVC in XP variant fibroblasts. This effect was reversed by expression of DNA polymerase $\eta$, indicating that translesion synthesis of UVC-induced pyrimidine dimers by DNA pol $\eta$ protects human fibroblasts against UVC genotoxic effects even when other DNA repair functions are compromised by caffeine.
\end{abstract}

\section{Keywords}

Caffeine; Checkpoints; DNA repair; ATM; ATR; Ionizing radiation; Ultraviolet radiation

\footnotetext{
(C) 2003 Elsevier B.V. All rights reserved.

${ }^{*}$ Corresponding author. Present address: Tel.: +1-919-966-8209; fax: +1-919-966-9673. wkarlk@med.unc.edu (W.K. Kaufmann). ${ }^{1}$ Current address: School of Biomedical Sciences, University of Ulster at Coleraine, Coleraine, Northern Ireland.

The contents of this article are solely the responsibility of the authors and do not necessarily represent the official views of the funding agencies.
} 


\section{Introduction}

Caffeine occupies an important niche in the cell cycle checkpoint field. Not only does it help bleary-eyed scientists concentrate on their experiments, it directly inhibits the checkpoint kinases, ATM and ATR [1,2]. Indeed, caffeine's ability to reverse delays in cell proliferation [3] was known before ATM and ATR were identified [4-6] and even before the concept of checkpoints was originated [7]. Caffeine is not a specific inhibitor of ATM and ATR, however, and many of its physiologic activities derive from its action on other enzymes, such as cyclic AMP phosphodiesterase [8]. Studies examining the effects of caffeine on cellular responses to DNA damage are motivated by reproducible demonstrations that it enhances the toxicity of radiations $[9,10]$ and chemical carcinogens $[11,12]$.

Caffeine inhibits ATM and ATR in a dose-dependent fashion. The concentration that inhibits ATM by $50 \%$ in vitro is $1 \mathrm{mM}$ and the $50 \%$ inhibitory concentration for ATR is about $3 \mathrm{mM}$ [1]. These concentrations define the range at which caffeine effectively reverses cell cycle checkpoints and enhances cytotoxicity in carcinogen-damaged cells $[3,9,13]$ without significant toxicity of its own. Lower concentrations are less effective at reversing checkpoint function and higher concentrations cause a reduction in DNA synthesis associated with cytotoxicity [13].

The enhancing effects of caffeine on cytotoxicity in carcinogen-damaged cells may derive from its reversal of checkpoints that act in S or G2. For ionizing radiations (IR), caffeine produces maximal enhancement of cytotoxicity on late S/G2 cells [9], whereas for UVC maximal enhancement occurs in S [14]. These results are rationalized by the knowledge that DNA repair protects cells against the lethal effects of carcinogen-induced damage [15] and the expectation that reducing the time available for repair in proliferating cells reduces repair efficiency. DNA double strand breaks are believed to be the lethal lesion induced by ionizing radiation, and this complex lesion may require an hour or more for repair [16]. Provision of an extra hour or two for repair before entry into mitosis, when chromosome condensation likely blocks further repair and permanently fixes the double strand break, would appear to be beneficial. Several studies have shown that reversal of checkpoint function using caffeine [10,17] and UCN-01 [18] doubled the toxicity of IR in human cancer cell lines.

Caffeine enhances the cytotoxicity of ultraviolet radiation (UVC) by its effect on damaged $\mathrm{S}$ phase cells. Here the issue is complicated by the nature of UVC-induced cellular damage and its mechanism of toxicity. UVC-induced cyclobutane pyrimidine dimers and 6-4 pyrimidine-pyrimidone adducts in DNA are repaired by nucleotide excision repair. It is during replication of UVC-damaged DNA that mutations and chromosomal aberrations are induced [19-21], and repair of photoproducts before DNA replication can provide significant protection against such genotoxic outcomes. However, inactivation of colony formation in human skin fibroblasts is rather invariant across the cell cycle [19], suggesting that the blockage of transcription of vital genes, and not DNA replication errors, accounts for inactivation of colony formation. 
Nucleotide excision repair and especially transcription-coupled repair provide significant protection against UVC-induced genotoxicity, reducing the lethal effects of UVC by about 10-fold [22]. A system of post-replication repair that includes efficient translesion synthesis of cyclobutane pyrimidine dimers by DNA pol $\eta$ also provides a measure of protection. Accurate translesion synthesis by DNA pol $\eta$ reduces mutagenesis by a factor of 4 [20], and decreases clastogenesis and cytotoxicity by a factor of two-fold or less [20,23]. Caffeine is also known to inhibit the repair of gaps in daughter-strand DNA in UVC-damaged cells [24]. The effects of caffeine are especially notable in XP variant cells [24], which lack DNA pol $\eta$ and must rely upon other more error-prone mechanisms of replication through UVCinduced photoproducts. Thus, while caffeine is now known to reverse an ATR-dependent S checkpoint that slows the rate of replicon initiation in UVC-treated cells [25], it may have an additional effect on pol $\eta$-independent bypass of cyclobutane pyrimidine dimers, which could involve translesion synthesis by other DNA polymerases or recombinational repair of daughter-strand gaps.

The studies reported here were undertaken with a motivation to define more fully the biological effects of caffeine in normal human fibroblasts (NHF). We applied sensitive and quantitative measures of cell cycle checkpoint function to monitor DNA damage responses in G1, S and G2 cells. While caffeine was found to reverse the S and G2 checkpoint responses to IR, it had very little effect on G1 checkpoint function, implying that ATM is less sensitive to caffeine in G1. Moreover, caffeine itself was found to induce an ATM- and p53-independent G1 delay, which was saturated at $2 \mathrm{mM}$ concentration of the drug. The mechanism of this biological response remains a mystery. While caffeine also reversed the ATR-dependent S checkpoint response to UVC, it produced very little enhancement of UVC-induced inhibition of cell proliferation in normal human fibroblasts (NHF). In contrast, caffeine enhanced the UVC-induced inhibition of XP variant cell proliferation by eight-fold, and this hypersensitivity was corrected by transduction of DNA pol $\eta$. This result is consistent with an emerging model that ATR (and downstream effectors) help to stabilize blocked growing points to prevent replication fork collapse and lethal cytogenetic damage [26,27].

\section{Materials and methods}

\subsection{Cell lines and culture conditions}

Normal human fibroblasts (NHF1) were derived from neonatal foreskin [28]. Ataxia telangiectasia (AT) and xeroderma pigmentosum variant (XP-V) correspond to dermal fibroblasts from affected individuals. The original mutant fibroblast strains were obtained from the NIGMS Human Genetic Cell Repository (GM02052A, AT) and the American Type Culture Collection (CRL1162, XP-V, strain XP4BE). Immortalized cell lines from these strains of human fibroblasts were obtained by ectopic expression of human telomerase (hTERT), as previously described [25]. The derivative cell lines described below are also immortalized. For simplicity, we refer to the immortalized normal human fibroblasts as F1hTERT. XP-V fibroblasts (CRL1162-hTERT) were complemented for expression of wildtype human DNA pol $\eta$ (CRL1162 + XPV) by infection with a replication-defective retrovirus carrying the XPV cDNA (a generous gift from Dr. Fumio Hanaoka, Osaka 
University) and the neomycin-resistance gene under control of the same viral promoter (pLXIN). An isogenic cell line carrying the empty vector (CRL1162 + LXIN) was derived in parallel. The same strategy was used to derive NHF1 fibroblasts expressing human papilloma virus (HPV) type 16 E6 oncoprotein (F1-hTERT + E6) or the vector control (F1hTERT + LXIN). Detailed characterization of these derivative cell lines will be published elsewhere.

Fibroblasts were maintained in Dulbecco's modified Eagle's medium (Invitrogen) supplemented with $2 \mathrm{mM}$ glutamine (Invitrogen) and, in NHF1 cultures, $10 \%$ fetal bovine serum (FBS, Sigma), in AT cultures, 15\% FBS, and, in XP-V cultures, 10\% FBS and 200 $\mu \mathrm{g} / \mathrm{ml}$ Geneticin (Invitrogen). All cell lines were maintained at $37^{\circ} \mathrm{C}$ in a humidified atmosphere of $5 \% \mathrm{CO}_{2}$.

\subsection{Cell treatment and irradiation}

Caffeine (concentrations indicated in figure legends) was added to the culture medium 30 min prior to irradiation and remained for the duration of the experiment. For UVC irradiation, culture medium was removed and reserved. Cultures were washed once with warm Hank's balanced salt solution (HBSS, Invitrogen), then placed uncovered under a UV lamp emitting primarily $254 \mathrm{~nm}$ radiation at a fluence rate of $0.5 \mathrm{~J} / \mathrm{m}^{2} / \mathrm{s}$. Reserved medium was added back and the cultures incubated for the indicated periods of time. Cells were exposed to ionizing radiation (gamma rays) in their culture medium, using a ${ }^{137} \mathrm{Cs}$ source at a dose rate of $0.84 \mathrm{~Gy} / \mathrm{min}$.

\subsection{DNA synthesis assay}

Logarithmically growing cells were plated at a density of $2.5 \times 10^{5}$ cells per $60 \mathrm{~mm}$ dish and grown at $37{ }^{\circ} \mathrm{C}$ for $36-48 \mathrm{~h}$ in medium containing $5 \mathrm{nCi} / \mathrm{ml}$ of $\left[{ }^{14} \mathrm{C}\right]$ thymidine (ICN Radiochemicals) to uniformly label DNA. Radioactive medium was replaced with fresh medium to chase $\left[{ }^{14} \mathrm{C}\right]$-labeled precursors into DNA for at least $3 \mathrm{~h}$. The effect of caffeine concentration on DNA synthesis was measured by adding to the culture medium $5 \%$ volume of solvent (PBS) containing caffeine at various concentrations and incubating the cultures at $37{ }^{\circ} \mathrm{C}$ for $30 \mathrm{~min}$, and then pulse-labeling DNA with $10 \mu \mathrm{Ci} / \mathrm{ml}\left[{ }^{3} \mathrm{H}\right]$ thymidine for $15 \mathrm{~min}$. The time course of inhibition of DNA synthesis was measured by adding solvent only or 2 $\mathrm{mM}$ caffeine to the cultures, incubating them for $30 \mathrm{~min}$ to $8 \mathrm{~h}$ (see figure legend), and then pulse-labeling DNA as indicated above. Radioactive medium was removed and plates washed twice with cold PBS, before adding $3 \mathrm{ml}$ of cold $4 \%$ trichloroacetic acid (TCA) and incubating at $4{ }^{\circ} \mathrm{C}$ for $30 \mathrm{~min}$. After washing the plates with cold $4 \%$ TCA and air drying at $4{ }^{\circ} \mathrm{C}$, the fixed cells were dissolved in $0.4 \mathrm{M} \mathrm{NaOH}$ and transferred to test tubes. Acidinsoluble material was collected on GF/C microfibre glass filters for measurement of radioactivity by liquid scintillation counting. Net ${ }^{3} \mathrm{H}$ radioactivity corrected for ${ }^{14} \mathrm{C}$ spillover was normalized for cell number (total ${ }^{14} \mathrm{C}$ radioactivity). Average ${ }^{3} \mathrm{H} /{ }^{14} \mathrm{C}$ ratios from triplicate cultures were taken as the specific activity of incorporation of $\left[{ }^{3} \mathrm{H}\right]$ thymidine in DNA and as measurements of DNA synthesis rates in cells treated with caffeine. 


\subsection{Velocity sedimentation analysis of nascent DNA}

The velocity sedimentation methodology used to determine the steady-state distribution of sizes of nascent DNA 30-45 min after irradiation of log phase cultures with either $1 \mathrm{~J} / \mathrm{m}^{2}$ UVC or 1.5 Gy IR has been described previously [23,29].

\subsection{Western-blot analyses}

These were performed essentially as described [25]. Briefly, logarithmically growing cells were seeded at $10^{6}$ per $100 \mathrm{~mm}$ dish and incubated for $40 \mathrm{~h}$. Cultures were treated as specified in the figure legends, harvested by trypsinization, washed once in PBS, and resuspended in lysis buffer (10 mM sodium phosphate buffer, pH 7.2, 1 mM EDTA, $1 \mathrm{mM}$ EGTA, $150 \mathrm{mM} \mathrm{NaCl}, 1 \%$ NP40, supplemented with $10 \mathrm{mM}$ 4-(2-aminoethyl) benzenesulfonyl fluoride (AEBSF), $10 \mathrm{mM} \beta$-glycerophosphate, $10 \mathrm{mM}$ sodium orthovanadate, and $10 \mu \mathrm{g} / \mathrm{ml}$ of leupeptin and aprotinin). Protein concentrations were determined using the Bio-Rad $\mathrm{D}_{C}$ Protein Assay (Bio-Rad Laboratories). Samples containing equal amounts of protein were mixed with an equal volume of $2 \times$ Laemmli sample buffer (125 mM Tris-HCl, pH 6.8, 4\% SDS, 20\% glycerol) containing 5\% $\beta$ mercaptoethanol, boiled, and separated by SDS-PAGE. Proteins were transferred to nitrocellulose and probed with antibodies against p53 (DO1; Santa Cruz), p21 Cip1/Waf1 (Labvision), phosphoserine-15 p53 (Cell Signaling), actin (Santa Cruz), and DNA pol $\eta$ (a generous gift from Dr. Fumio Hanaoka, Osaka University [30]).

\subsection{G1 checkpoint analysis}

Cells were irradiated and/or treated with caffeine as indicated in the figure legends. Six hours after irradiation or continuous incubation in caffeine, $10 \mu \mathrm{M} 5^{\prime}$-bromo-2'-deoxyuridine (BrdU; Sigma) was added to the medium and the cultures incubated for another $2 \mathrm{~h}$. Cells were harvested, washed with PBS, and fixed in PBS containing 67\% ethanol. Cells were stained with propidium iodide and fluorescein isothiocyanate (FITC)-conjugated anti-BrdU antibody (Becton Dickinson) as described [31]. Flow cytometric analyses were done on a FACScan machine using Summit software (Cytomation Inc.).

\subsection{G2 checkpoint analysis}

Mitotic cells were quantified via flow cytometric analysis by enumerating cells with $4 \mathrm{~N}$ DNA that stained positive for the mitotic cell-specific epitope phosphohistone $\mathrm{H} 3$, as previously described $[32,33]$. Briefly, cells were harvested by tripsinization, washed with PBS, and fixed in $1 \%$ formaldehyde in PBS. Fixed cells were then rinsed once with PBS containing $67 \%$ ethanol and resuspended in PBS containing $0.5 \mu \mathrm{g}$ of anti-phosphohistone $\mathrm{H} 3$ antibody (Upstate Biotechnology), 5\% FBS, $0.1 \%$ sodium azide, and $150 \mathrm{mM} \mathrm{NaCl}$ (IFA solution). Cells were washed twice in IFA and stained with propidium iodide and FITC-conjugated anti-mouse antibody (Santa Cruz). Flow cytometric analyses were done on a FACScan machine using Summit software (Cytomation Inc.).

\subsection{Cytotoxicity assay}

UVC-induced inhibition of cell proliferation was measured as an index of cytotoxicity as previously described [34]. Briefly, logarithmically growing cells were plated at a density of 
$1 \times 10^{4}$ (F1-hTERT) or $1.5 \times 10^{4}$ (CRL1162-hTERT and derivative cell lines) cells per well in 6-well dishes. Twenty-four hours later, the cells were irradiated with the indicated fluences of UVC and fed with fresh medium $\pm 1 \mathrm{mM}$ caffeine. After 2 days, the old medium was replaced with fresh medium $\pm 1 \mathrm{mM}$ caffeine. The following day ( $72 \mathrm{~h}$ after UVC irradiation), cells were incubated with $1 \mu \mathrm{Ci} / \mathrm{ml}\left[{ }^{3} \mathrm{H}\right]$ thymidine for $1 \mathrm{~h}$. As described above, cells were washed and fixed with $4 \%$ TCA, and radioactivity in acid-insoluble material measured by liquid scintillation counting. Reduction in the incorporation rate of $\left[{ }^{3} \mathrm{H}\right]$ thymidine (average of triplicate cultures) was taken as an indirect measurement of the degree of inhibition of proliferation of cells exposed to UVC. Preliminary experiments established that under the culture conditions described here, control cultures remained in log phase and did not reach confluence prior to the end of the experiment. This assay produced results in concordance with the UVC-induced inhibition of colony formation in human fibroblasts, which is a common measure of cytotoxicity in this cell type [35,36].

Colony formation was measured in logarithmically growing F1-hTERT cells that were plated at 500 or 750 cells per $100 \mathrm{~mm}$ diameter dish and incubated for $18 \mathrm{~h}$ or less before exposure to increasing fluences of UVC (5-10 dishes per fluence). Cells were incubated for 2 weeks, with one medium change on day 8 , then cell colonies were fixed with methanol:acetic acid $(3: 1(\mathrm{v} / \mathrm{v}))$ and stained with Giemsa. Only colonies with $>50$ cells were counted. The relative colony-forming efficiency of UVC-treated cells was expressed as a fraction of the sham-treated controls. This index of cell proliferation (clonal expansion) was compared to that determined in the short-term assay based on $\left[{ }^{3} \mathrm{H}\right]$ thymidine incorporation described above.

\section{Results}

\subsection{Caffeine inhibits $G 2$ checkpoint function}

Incubation with caffeine following exposure to IR was shown previously to reverse radiation-induced G2 delay in HeLa cells [3]. It also enhanced IR-induced cytotoxicity in a cycle phase-dependent manner with synchronized G2 cells displaying the greatest increment of cell killing [9,37]. Flow cytometry was used to quantify G2 checkpoint function in diploid human fibroblasts that were immortalized by expression of telomerase [38]. Normal fibroblasts displayed $2 \%$ of cells with 4N DNA content and expression of a mitosis-specific phosphohistone H3 (Fig. 1A). Treatment with 1.5 Gy of IR $2 \mathrm{~h}$ before cell harvest reduced the fraction of these mitotic cells to $0.1 \%$, corresponding to $5 \%$ of control and reflecting a radiation-induced G2 delay. AT fibroblasts displayed an attenuation of this response to IR with a mitotic fraction in irradiated cells that was $50 \%$ of that in the sham-treated control culture (Fig. 1B). These results confirm previous reports that the radiation-induced G2 delay is a checkpoint response and that it is defective in AT cells [39,40]. Incubation with $2 \mathrm{mM}$ caffeine for $2.5 \mathrm{~h}$ had little effect on the mitotic fraction in cultures of sham-treated normal and AT fibroblasts, but reversed the radiation-induced inhibition of mitosis by $90-100 \%$ (Fig. 1).

AT cells displayed a 50\% inhibition of mitosis post-irradiation, and this inhibition likely reflects the activity of the ATM-and rad3-related checkpoint kinase, ATR. We and others have shown that expression of a kinase-inactive ATR also attenuates the G2 checkpoint 
response to IR [5,38]. Our analyses suggest that ATM and ATR contribute equally to the IRinduced $\mathrm{G} 2$ delay. Inactivation of either enzyme attenuates the $\mathrm{G} 2$ checkpoint response by about $50 \%$. The full ablation by caffeine of $\mathrm{G} 2$ checkpoint response has been attributed to its inhibition of ATM [41]. A recent publication disputes the interpretation that ATM and ATR are directly inhibited by caffeine in cultured cells [42]. The new findings show that ATM autophosphorylation and ATM/ATR-dependent phosphorylation of Chk1 are resistant to caffeine. These results imply that caffeine inhibits the signaling cascades in the G2 checkpoint response that are downstream of ATM, ATR and Chk1.

\subsection{Caffeine inhibits $S$ checkpoint function}

Caffeine-enhancement of cytotoxicity by UVC also is cycle phase-dependent but $\mathrm{S}$ phase cells display the greatest sensitivity. Synergistic lethality by caffeine with nitrogen mustard was correlated with reversal of the mustard-induced inhibition of replicon initiation in S phase cells [12,13]. The IR-induced S checkpoint response of inhibition of replicon initiation is ATM-dependent, as shown in Fig. 2. While normal fibroblasts responded to IR with a selective inhibition of incorporation of radiolabeled precursor in low molecular weight nascent DNA intermediates, AT cells were resistant to this effect, displaying the phenotype of radioresistant DNA synthesis. Treatment with caffeine reversed the $S$ checkpoint response to IR in normal fibroblasts. AT cells displayed a normal S checkpoint response to UVC, with $1 \mathrm{~J} / \mathrm{m}^{2}$ producing the same selective inhibition of replicon initiation in normal and AT cells. We have recently demonstrated that the UVC-induced inhibition of replicon initiation is an ATR- and Chk1-dependent $\mathrm{S}$ checkpoint response [25]. Incubation with caffeine post-UVC reversed the inhibition of replicon initiation in normal and AT fibroblasts (Fig. 2). Thus, caffeine also ablated the $\mathrm{S}$ checkpoint responses to radiationinduced cellular damage.

In view of the recent report that caffeine does not inhibit ATM and ATR in cells [42], we performed a western immunoblot analysis of Chk1 phosphorylation in HeLa cells after treatment with UVC and IR. While both $1 \mathrm{~J} / \mathrm{m}^{2} \mathrm{UVC}$ and 5 Gy IR induced the phosphorylation of Chk1 at ser317 within 45 min after treatment, these effects were not blocked by caffeine (results not shown), confirming the observations by Cortez [42].

\subsection{Caffeine does not inhibit G1 checkpoint function but induces G1 delay}

To complete our survey of caffeine effects on cell cycle checkpoint function in diploid human fibroblasts, we quantified radiation-induced G1 checkpoint function in the presence or absence of caffeine. Treatment of normal human fibroblasts with 1.5 Gy IR produced a selective $97 \%$ reduction of cells in the first half of S phase, as seen by labeling cells with BrdU 6-8 $\mathrm{h}$ after irradiation (Fig. 3A). This selective emptying of the early $\mathrm{S}$ compartment is a checkpoint response to IR, as AT fibroblasts were resistant to this effect (Fig. 3B). No significant increment of $\mathrm{S}$ phase cells was observed in cultures of irradiated normal human fibroblasts upon post-irradiation incubation with caffeine (Figs. 3A and 4A). However, caffeine alone at $2 \mathrm{mM}$ reduced the fraction of cells in early S phase by $70-80 \%$ in normal and AT fibroblast cultures (Figs. 3 and 5A). Quantification of G1 checkpoint function in three independent experiments using normal human fibroblasts is shown in Fig. 4. While IR reduced the mean fractions of fibroblasts in the first half of S phase from 12 to $0.7 \%$, a 
similar fraction of $0.7 \%$ of cells were in early $\mathrm{S}$ phase following post-irradiation incubation with $2 \mathrm{mM}$ caffeine. Caffeine alone reduced the fraction of cells in early $\mathrm{S}$ phase from 12 to 4\%. Consequently, when expressed as a percentage of the sham-treated control (Fig. 3), caffeine-treated cultures appeared to have an attenuation of the G1 checkpoint response to IR. Such an attenuation became more evident when the caffeine concentration was increased to $5 \mathrm{mM}$ (Fig. 3A), a concentration that significantly inhibits DNA synthesis in human fibroblasts, as discussed below (Fig. 6). In comparison to the 90-100\% reversal of G2 (Fig. 1) and S (Fig. 2) checkpoint responses to IR produced by $2 \mathrm{mM}$ caffeine, the G1 checkpoint response to IR (Fig. 3A) was substantially non-responsive to this concentration of caffeine (Figs. 3A and 4A). In the same experiments, quantification of cells in the G2/M compartment $8 \mathrm{~h}$ post-IR revealed the expected IR-induced accumulation associated with G2 delay (Fig. 4B). Post-irradiation incubation with caffeine reversed this effect, indicating that in the same population of cells in which G1 arrest was little affected by caffeine, the G2 checkpoint response was completely abrogated.

Flow scattergrams and quantitation of cells in the first half of $\mathrm{S}$ indicated that $2 \mathrm{mM}$ caffeine alone induced a significant G1 delay in normal and AT fibroblasts (Figs. 3 and 5A). To determine whether the G1 delay that was induced by caffeine required p53 signaling, we tested whether inactivation of p53 with HPV16E6 oncoprotein would eliminate this G1 delay. Incubation of E6-expressing and vector-control fibroblasts with 2 or $5 \mathrm{mM}$ caffeine for $8.5 \mathrm{~h}$ produced the same $70-80 \%$ reduction of cells in the first half of S phase (Fig. 5A). This finding indicated that $\mathrm{p} 53$ function, and any other function affected by HPV16E6, was not required for the caffeine-induced G1 delay.

ATM phosphorylates p53 on ser15, and ATM signaling is required for induction of p53 protein after IR. Activation of p53 induces synthesis of the cyclin-dependent kinase inhibitor p21 ${ }^{\mathrm{Cip} 1 / \mathrm{Waf} 1}$ as the effector of the ATM- and p53-dependent G1 checkpoint response. Western immunoblot analysis was done to test whether caffeine affected p53 signaling in response to IR. While treatment with IR induced $\mathrm{p} 53$ protein, $\mathrm{p} 53$-ser 15 phosphorylation and $\mathrm{p} 21^{\mathrm{Cip} 1 / \mathrm{Waf} 1}$ expression in normal fibroblasts, these effects were not reversed by incubation in caffeine (Fig. 5B). Incubation with caffeine induced neither p53 or p21 but, rather, reduced expression of $\mathrm{p} 21^{\mathrm{Cip} 1 / \mathrm{Waf} 1}$ in both irradiated and unirradiated cells. As p21 $1^{\mathrm{Cip} 1 / \mathrm{Waf} 1}$ is, in part, growth-regulated, this may reflect the inhibition of cell proliferation induced by caffeine as described above. The caffeine-induced G1 delay therefore appears to be independent of the ATM/p53/p21 Cip1/Waf1 signaling pathway.

\subsection{Caffeine inhibits DNA synthesis}

Previous studies of caffeine using transformed or cancer cell lines showed that concentrations higher than $3 \mathrm{mM}$ inhibited DNA synthesis and inactivated clonal expansion [13]. To explore this dose-dependence on diploid human fibroblasts, we monitored incorporation of $\left[{ }^{3} \mathrm{H}\right]$ thymidine after a brief incubation with various concentrations of caffeine, or after prolonged incubation with $2 \mathrm{mM}$ caffeine (Fig. 6). Normal and AT fibroblasts were both sensitive to inhibition of incorporation of $\left[{ }^{3} \mathrm{H}\right]$ thymidine by high concentrations of caffeine. While 1-2 mM inhibited DNA synthesis on average by about $30 \%, 30$ min incubation with $5 \mathrm{mM}$ reduced $\left[{ }^{3} \mathrm{H}\right]$ thymidine incorporation by $60 \%$ and 10 
$\mathrm{mM}$ reduced it by $>80 \%$ (Fig. 6A). During the first $2 \mathrm{~h}$ of incubation with $2 \mathrm{mM}$ caffeine, incorporation of $\left[{ }^{3} \mathrm{H}\right]$ thymidine varied from 60 to $70 \%$ of control in AT cells and $85-95 \%$ of control in normal fibroblasts (Fig. 6B). Thereafter, incorporation declined more or less continuously, such that incorporation was reduced to $30 \%$ of control after $8 \mathrm{~h}$ incubation in caffeine. This degree of inhibition (70\%) was similar to the reduction in S phase cells that were labeled with BrdU 6.5-8.5 h after addition of caffeine. The inhibition of incorporation of $\left[{ }^{3} \mathrm{H}\right]$ thymidine $4-8 \mathrm{~h}$ after addition of $2 \mathrm{mM}$ caffeine therefore reflects the caffeineinduced G1 delay.

\subsection{DNA pol $\eta$ suppresses the enhancement of UVC cytotoxicity by caffeine}

Although a variety of data suggest that caffeine enhancement of cytotoxicity may be due to abrogation of protective cell cycle checkpoint function, other effects of caffeine on DNA repair might also contribute. For example, pol $\eta$-dependent translesion synthesis of UVCinduced pyrimidine dimers provides a modest increment of protection against cytotoxicity over that afforded by nucleotide excision repair $[43,44]$. Caffeine has long been known to interfere with processes commonly known as post-replication repair $[24,45,46]$, inhibiting in particular an ill-defined post-replication repair pathway that is operational in XP variant cells $[35,47,48]$. As shown in Fig. 2, caffeine does not appear to interfere with pol $\eta$ dependent translesion synthesis, as the inhibition of DNA chain elongation was not enhanced in normal human and AT fibroblasts by post-UVC incubation with caffeine. It is conceivable that caffeine may inhibit a pol ๆ-independent post-replication repair process, as suggested by one notable study. Lehmann [46] showed that the average size of nascent DNA strands that were synthesized in pol $\eta$-defective XP variant cells in the presence of caffeine was equivalent to the average spacing between pyrimidine dimers. This observation suggested that the caffeine-sensitive post-replication repair pathway retained by XP variant cells involves pol eta-independent mechanism(s) of repair of daughter-strand gaps formed across UVC-induced DNA photoproducts. To disclose an effect of caffeine on postreplication repair, we employed an assay that quantified DNA synthesis in diploid normal and XP variant fibroblasts $72 \mathrm{~h}$ after treatment with UVC. As illustrated in Fig. 7A, this short-term assay for inhibition of cell proliferation [34] agreed very well with an assay of colony formation as surrogates of radiation-induced cytotoxicity. Normal human fibroblasts displayed a dose-dependent decrease in colony-formation efficiency or inhibition of DNA synthesis post-UVC with a $60 \%$ reduction at $8 \mathrm{~J} / \mathrm{m}^{2}$ and $90 \%$ reduction at $12 \mathrm{~J} / \mathrm{m}^{2}$. Addition of $1 \mathrm{mM}$ caffeine for the $72 \mathrm{~h}$ post-UVC had only a small effect in normal human fibroblasts. XP variant fibroblasts (CRL1162-hTERT) displayed increased sensitivity to UVC with $70 \%$ inhibition of DNA synthesis after $4 \mathrm{~J} / \mathrm{m}^{2}$ and $>90 \%$ inhibition after $8 \mathrm{~J} / \mathrm{m}^{2}$ (Fig. 7B). In contrast to the minor enhancement seen in normal fibroblasts, incubation of XP variant cells with caffeine post-UVC produced a significant increment of inhibition of DNA synthesis. While $4 \mathrm{~J} / \mathrm{m}^{2}$ reduced synthesis to $30 \%$ of the control in the absence of caffeine, in its presence $4 \mathrm{~J} / \mathrm{m}^{2}$ reduced synthesis to $2 \%$ of control. Similarly, in the absence of caffeine $2 \mathrm{~J} / \mathrm{m}^{2}$ reduced synthesis to $70 \%$ of control but in the presence of caffeine $2 \mathrm{~J} / \mathrm{m}^{2}$ reduced synthesis to $10 \%$ of control. In summary, the short-term assays [34], in full agreement with measurements of colony formation [49], confirmed that XP variant cells display hypersensitivity to caffeine enhancement of cytotoxicity by UVC. 
The CRL1162-hTERT line was transduced with DNA pol $\eta$ or the empty vector by infection with a replication-defective retrovirus. Fig. 8A illustrates the expression of DNA pol $\eta$ in the CRL1162+XPV cell line. XP variant cells that were infected with the empty vector alone displayed the expected hypersensitivity to UVC. XP variant cells that were transduced with DNA pol $\eta$ displayed sensitivity to UVC equivalent to that seen in the F1-hTERT normal fibroblast line (Fig. 8B). Thus, caffeine-enhancement of cytotoxicity in XP variant cells was related to the defect in expression of DNA pol $\eta$.

\section{Discussion}

This survey of the effects of caffeine on DNA metabolism in diploid human fibroblast strains confirmed the inhibition of ATM- and ATR-dependent S and G2 checkpoint function and enhancement of UVC cytotoxicity in DNA pol $\eta$-defective XP variant cells. Unexpectedly, especially in view of a previous report [50], caffeine at $2 \mathrm{mM}$ concentration did not inhibit ATM-dependent G1 checkpoint function. There was no decrement of IRinduced G1 arrest under conditions in which G2 delay was ablated. This result suggests that ATM signaling in G1 cells may be resistant to caffeine. The fact that caffeine also induced G1 delay in the absence of damage reveals a potential limitation in the use of checkpoint inhibitors to enhance cytotoxicity of chemo- and radiotherapies. Although the magical reversal of checkpoint function by caffeine is now well established, several of the biological effects of caffeine identified here remain a mystery.

Previous studies had indicated that caffeine inhibited ATM and ATR signaling in checkpoints acting in G1, S and G2 [2,41,51]. We were not surprised therefore to find that caffeine fully abrogated ATM-and ATR-dependent S and G2 checkpoint responses in IRand UVC-treated human fibroblasts. We were surprised to find that caffeine did not abrogate ATM-and p53-dependent G1 checkpoint response to IR under conditions in which G2 delay was fully reversed. ATM-dependent phosphorylation of p53 at ser15 and p53-dependent induction of $\mathrm{p} 21^{\mathrm{Cip} 1 / \mathrm{Waf} 1}$ were not inhibited by caffeine, indicating that ATM function in G1 cells was insensitive to caffeine. Recently, Cortez [42] showed that caffeine did not inhibit ATM autophosphorylation nor ATM- and ATR-dependent phosphorylation of Chk1 in cells with DNA damage, even though it inhibited the G2 checkpoint response to DNA damage. We confirmed that caffeine did not block ATM- and ATR-dependent phosphorylation of Chk1. These results suggest that caffeine must interfere with signaling downstream of ATM, ATR, and Chk1 to abrogate S and G2 checkpoint responses to DNA damage.

The S checkpoint response to IR-induced DNA damage has been shown to involve signaling through ATM and Chk2 to Cdc25A [52], and the G2 checkpoint response to IR includes signaling from ATM, ATR and Chk1 to Cdc25C [53]. The Cdc25 protein phosphatases (Cdc25A, Cdc25B and Cdc25C) are dual specificity phosphatases that activate Cdk1 and Cdk2 by removing inhibitory phosphotyrosine and phosphothreonine residues from the ATP binding site [54]. One arm of DNA damage checkpoint responses includes ATM-dependent phosphorylation of Cdc25's by Chk1 and Chk2. Phosphorylation of Cdc25A leads to its proteolysis [52] while phosphorylation of $\mathrm{Cdc} 25 \mathrm{C}$ creates a 14-3-3 binding site to sequester the protein in the cytoplasm and possibly inhibit activity [53,55]. The net effect of 
phosphorylation of Cdc25's is to sustain inhibition of Cdk1 and Cdk2, which are required for initiation of mitosis and DNA synthesis, respectively. As caffeine does not block intracellular ATM autophosphorylation and phosphorylation of Chk1 and Chk2 [42], the Cdc25 pathway does not appear to be the target of checkpoint abrogation by caffeine.

Inactivation of the $\mathrm{Cdc} 25 \mathrm{C}$ regulatory pathway by expression of $\mathrm{Cdk} 1 \mathrm{AF}$, a nonphosphorylatable form of Cdk1, produced only a modest reversal of $\mathrm{G} 2$ checkpoint function [56]. Subsequent studies demonstrated that cyclin B1/Cdk1 complexes were also regulated by cellular compartmentalization, with the Crm1 nuclear exporter actively sequestering cyclin B1 in the cytoplasm $[57,58]$. Phosphorylation of cyclin B1 by the Polo-like kinase, Plk1, blocks Crm1-mediated nuclear export allowing nuclear accumulation of cyclin B1 [59]. Plk1 is inhibited by IR-induced DNA damage by an ATM-dependent mechanism $[60,61]$. The net effect of ATM/Plk1/cyclin B1 signaling is to block nuclear accumulation of cyclin B1/Cdk1 complexes, thereby preventing entry into mitosis. The ATR-dependent decatenation checkpoint also appears to rely upon inhibition of Plk1 to block the onset of mitosis [62]. Caffeine has been shown to block the IR-induced inhibition of Plk1 [61] suggesting at least one mechanism whereby caffeine abrogates G2 checkpoint function.

Quantification of $\left[{ }^{3} \mathrm{H}\right]$ thymidine incorporation is a sensitive measure of UVC-induced genotoxicity and cytotoxicity. Caffeine enhanced genotoxicity in UVC-treated XP variant cells and this effect was fully reversed by expression of DNA pol $\eta$. We had originally interpreted this phenomenon of caffeine enhancement of genotoxicity to reflect a requirement for ATR to prevent the demise of replication forks blocked at cyclobutane pyrimidine dimers, in analogy to the requirement for Mec1 in alkylated yeast strains [63]. In view of the apparent insensitivity of intracellular ATR to caffeine this hypothesis in untenable. Treatment of XP variant cells with UVC leads to a condition in S phase cells with many blocked growing points and replicative gaps due to the absence of the bypass polymerase pol $\eta$. This condition may be similar to that produced by hydroxyurea in pol $\eta$ expressing cells, and the combination of hydroxyurea and caffeine is particularly lethal in mammalian cells [64]. These observations imply that there is a caffeine-sensitive pathway that stabilizes arrested replication forks or replicative gaps. The work of Lehmann [46] implies that this pol $\eta$-independent pathway may facilitate bypass of cyclobutane pyrimidine dimers. Work must now focus on the caffeine-sensitive steps of processing of nascent DNA at arrested replication forks and growing points. It will be particularly interesting to determine whether the caffeine-sensitive regulation of Plk1 intersects with signaling at arrested growing points.

The mechanism of caffeine-induced G1 delay remains to be determined. Caffeine has long been known to induce a G1 delay in mammalian cells [65-67], and we showed that caffeineinduced $\sim 75 \%$ inhibition of G1/S progression in diploid human fibroblast strains. ATM and p53 were not required as AT cells and cells expressing HPV16E6 to inactivate p53 also arrested in G1 when incubated in caffeine. The caffeine-induced G1 delay was not associated with induction of $\mathrm{p} 21^{\mathrm{Cip} 1 / \mathrm{Waf} 1}$. Previous studies of caffeine effects on the cell cycle have been devoted largely to cancer cell lines, which often display defects in G1 checkpoint function deriving from inactivation of $\mathrm{p} 53$ and pRB regulatory pathways. For example, HeLa cells express HPV18E6 and E7 to inactivate p53 and pRB. The fact that 
caffeine produced only a modest G1 delay in HeLa cells suggests that pRB may be required for the caffeine-induced G1 delay [3]. We had entertained the thought that the effect could be a DNA damage response. However, because p53 was not required and p21 Cip1/Waf1 was not induced by caffeine, this possibility appears unlikely. Caffeine might affect some component of the signaling pathway that inactivates $\mathrm{pRB}$ to promote $\mathrm{S}$ phase entry. Clearly caffeine does not inhibit cyclin $\mathrm{B} 1 / \mathrm{Cdk} 1$ which is the cyclin-dependent kinase that promotes $\mathrm{G} 2 / \mathrm{M}$ progression. As caffeine did not induce a dramatic inhibition of DNA synthesis at 1-2 $\mathrm{mM}$, it seems unlikely that it inhibits the cyclin $\mathrm{E} / \mathrm{Cdk} 2$ and cyclin $\mathrm{A} / \mathrm{Cdk} 2$ complexes that are required for initiation of replication and progression through S. Perhaps the cyclin D1/ Cdk4,6 complexes that are required for inactivation of $\mathrm{pRB}$ are sensitive to caffeine.

In summary, caffeine has the magical property of reversing $\mathrm{S}$ and $\mathrm{G} 2$ checkpoint function and reducing DNA repair in irradiated cells. Mysteries remain concerning how intracellular ATM and ATR checkpoint kinases resist caffeine, the nature of the caffeine-sensitive steps in the $\mathrm{S}$ and $\mathrm{G} 2$ checkpoints, and how caffeine induces G1 delay.

\section{Acknowledgments}

This work was supported in part by PHS grants CA55065, CA81343, and P30-CA16086 from the National Cancer Institute, and ES11012, ES11391, and P30-ES10126 from the National Institute of Environmental Health Sciences (NIEHS). TPH is a doctoral student supported by T32-ES07017 and DDL is the recipient of a postdoctoral fellowship from the International Agency for Research on Cancer.

\section{References}

1. Sarkaria JN, Busby EC, Tibbetts RS, Roos P, Taya Y, Karnitz LM, Abraham RT. Inhibition of ATM and ATR kinase activities by the radiosensitizing agent, caffeine. Cancer Res. 1999; 59:43754382. [PubMed: 10485486]

2. Blasina A, Price BD, Turenne GA, McGowan CH. Caffeine inhibits the checkpoint kinase ATM. Curr Biol. 1999; 9:1135-1138. [PubMed: 10531013]

3. Tolmach L, Jones RW, Busse PM. The action of caffeine on X-irradiated HeLa cells. I. Delayed inhibition of DNA synthesis. Radiat Res. 1977; 71:653-665. [PubMed: 897091]

4. Savitsky K, Bar-Shira A, Gilad S, Rotman G, Ziv Y, Vanagaite L, Tagle DA, Smith S, Uziel T, Sfez $\mathrm{S}$, et al. A single ataxia telangiectasia gene with a product similar to PI-3 kinase. Science. 1995; 268:1749-1753. [PubMed: 7792600]

5. Cliby WA, Roberts CJ, Cimprich KA, Stringer CM, Lamb JR, Schreiber SL, Friend SH. Overexpression of a kinase-inactive ATR protein causes sensitivity to DNA-damaging agents and defects in cell cycle checkpoints. Embo J. 1998; 17:159-169. [PubMed: 9427750]

6. Wright JA, Keegan KS, Herendeen DR, Bentley NJ, Carr AM, Hoekstra MF, Concannon P. Protein kinase mutants of human ATR increase sensitivity to UV and ionizing radiation and abrogate cell cycle checkpoint control. Proc Natl Acad Sci USA. 1998; 95:7445-7450. [PubMed: 9636169]

7. Hartwell LH, Weinert TA. Checkpoints: controls that ensure the order of cell cycle events. Science. 1989; 246:629-634. [PubMed: 2683079]

8. Vaugeois JM. Signal transduction: positive feedback from coffee. Nature. 2002; 418:734-736. [PubMed: 12181550]

9. Busse PM, Bose SK, Jones RW, Tolmach LJ. The action of caffeine on X-irradiated HeLa cells. II. Synergistic lethality. Radiat Res. 1977; 71:666-677. [PubMed: 911393]

10. Powell SN, DeFrank JS, Connell P, Eogan M, Preffer F, Dombkowski D, Tang W, Friend S. Differential sensitivity of p53(-) and p53(+) cells to caffeine-induced radiosensitization and override of G2 delay. Cancer Res. 1995; 55:1643-1648. [PubMed: 7712468]

11. Nomura T. Similarity of the mechanism of chemical carcinogen-initiated teratogenesis and carcinogenesis in mice. Cancer Res. 1977; 37:969-973. [PubMed: 403002] 
12. Murnane JP, Byfield JE, Ward JF, Calabro-Jones P. Effects of methylated xanthines on mammalian cells treated with bifunctional alkylating agents. Nature. 1980; 285:326-329. [PubMed: 7374784]

13. Murnane JP, Byfield JE, Chen CT, Wang CH. The structure of methylated xanthines in relation to their effects on DNA synthesis and cell lethality in nitrogen mustard-treated cells. Biophys J. 1981; 35:665-676. [PubMed: 7272456]

14. Domon M, Rauth AM. Ultraviolet-light irradiation of mouse L cells: effects on cells in the DNA synthesis phase. Radiat Res. 1969; 40:414-429. [PubMed: 4241913]

15. Maher, VM.; McCormick, JJ. Effect of DNA repair on the cytotoxicity and mutagenicity of UV irradiation and of chemical carcinogens in normal and xeroderma pigmentosum cells. In: Yuhas, JM., et al., editors. Biology of Radiation Carcinogensis. Raven Press; New York: 1976. p. 129-145.

16. Nevaldine B, Longo JA, Vilenchik M, King GA, Hahn PJ. Induction and repair of DNA doublestrand breaks in the same dose range as the shoulder of the survival curve. Radiat Res. 1994; 140:161-165. [PubMed: 7938463]

17. Russell KJ, Wiens LW, Demers GW, Galloway DA, Plon SE, Groudine M. Abrogation of the G2 checkpoint results in differential radiosensitization of G1 checkpoint-deficient and G1 checkpointcompetent cells. Cancer Res. 1995; 55:1639-1642. [PubMed: 7712467]

18. Wang Q, Fan S, Eastman A, Worland PJ, Sausville EA, O'Connor PM. UCN-01: a potent abrogator of G2 checkpoint function in cancer cells with disrupted p53. J Natl Cancer Inst. 1996; 88:956-965. [PubMed: 8667426]

19. Konze-Thomas B, Hazard RM, Maher VM, McCormick JJ. Extent of excision repair before DNA synthesis determines the mutagenic but not the lethal effect of UV radiation. Mutat Res. 1982; 94:421-434. [PubMed: 7110182]

20. Watanabe M, Maher VM, McCormick JJ. Excision repair of UV- or benzo[a]pyrene diol epoxideinduced lesions in xeroderma pigmentosum variant cells is 'error free'. Mutat Res. 1985; 146:285294. [PubMed: 3932847]

21. Kaufmann WK. Cell cycle checkpoints and DNA repair preserve the stability of the human genome. Cancer Metastasis Rev. 1995; 14:31-41. [PubMed: 7606819]

22. Cleaver JE. Common pathways for ultraviolet skin carcinogenesis in the repair and replication defective groups of xeroderma pigmentosum. J Dermatol Sci. 2000; 23:1-11. [PubMed: 10699759]

23. Cordeiro-Stone M, Frank A, Bryant M, Oguejiofor I, Hatch SB, McDaniel LD, Kaufmann WK. DNA damage responses protect xeroderma pigmentosum variant from UVC-induced clastogenesis. Carcinogenesis. 2002; 23:959-965. [PubMed: 12082017]

24. Lehmann AR, Kirk-Bell S, Arlett CF, Harcourt SA, de Weerd-Kastelein EA, Keijzer W, HallSmith P. Repair of ultraviolet light damage in a variety of human fibroblast cell strains. Cancer Res. 1977; 37:904-910. [PubMed: 837385]

25. Heffernan TP, Simpson DA, Frank AR, Heinloth AN, Paules RS, Cordeiro-Stone M, Kaufmann WK. An ATR-and Chk1-dependent S checkpoint inhibits replicon initiation following UVCinduced DNA damage. Mol Cell Biol. 2002; 22:8552-8561. [PubMed: 12446774]

26. Brown EJ, Baltimore D. Essential and dispensable roles of ATR in cell cycle arrest and genome maintenance. Genes Dev. 2003; 17:615-628. [PubMed: 12629044]

27. Casper AM, Nghiem P, Arlt MF, Glover TW. ATR regulates fragile site stability. Cell. 2002; 111:779-789. [PubMed: 12526805]

28. Boyer JC, Kaufmann WK, Cordeiro-Stone M. Role of postreplication repair in transformation of human fibroblasts to anchorage independence. Cancer Res. 1991; 51:2960-2964. [PubMed: 1903328]

29. Cistulli CA, Kaufmann WK. p53-dependent signaling sustains DNA replication and enhances clonogenic survival in $254 \mathrm{~nm}$ ultraviolet-irradiated human fibroblasts. Cancer Res. 1998; 58:1993-2002. [PubMed: 9581844]

30. Kannouche P, Broughton BC, Volker M, Hanaoka F, Mullenders LH, Lehmann AR. Domain structure, localization, and function of DNA polymerase eta, defective in xeroderma pigmentosum variant cells. Genes Dev. 2001; 15:158-172. [PubMed: 11157773] 
31. Kaufmann WK, Levedakou EN, Grady HL, Paules RS, Stein GH. Attenuation of G2 checkpoint function precedes human cell immortalization. Cancer Res. 1995; 55:7-11. [PubMed: 7805043]

32. Juan G, Traganos F, James WM, Ray JM, Roberge M, Sauve DM, Anderson H, Darzynkiewicz Z. Histone $\mathrm{H} 3$ phosphorylation and expression of cyclins A and B1 measured in individual cells during their progression through G2 and mitosis. Cytometry. 1998; 32:71-77. [PubMed: 9627219]

33. Xu B, Kim ST, Lim DS, Kastan MB. Two molecularly distinct G(2)/M checkpoints are induced by ionizing irradiation. Mol Cell Biol. 2002; 22:1049-1059. [PubMed: 11809797]

34. Yamada A, Masutani C, Iwai S, Hanaoka F. Complementation of defective translesion synthesis and UV light sensitivity in xeroderma pigmentosum variant cells by human and mouse DNA polymerase eta. Nucleic Acids Res. 2000; 28:2473-2480. [PubMed: 10871396]

35. Arlett CF, Harcourt SA, Broughton BC. The influence of caffeine on cell survival in excisiondeficient xeroderma pigmentosum and normal human cell strains following ultraviolet-light irradiation. Mutat Res. 1975; 33:341-346. [PubMed: 1214825]

36. Boyer JC, Kaufmann WK, Brylawski BP, Cordeiro-Stone M. Defective postreplication repair in xeroderma pigmentosum variant fibroblasts. Cancer Res. 1990; 50:2593-2598. [PubMed: 2109654]

37. Busse PM, Bose SK, Jones RW, Tolmach LJ. The action of caffeine on X-irradiated HeLa cells. III. Enhancement of X-ray-induced killing during G2 arrest. Radiat Res. 1978; 76:292-307. [PubMed: 156382]

38. Deming PB, Cistulli CA, Zhao H, Graves PR, Piwnica-Worms H, Paules RS, Downes CS, Kaufmann WK. The human decatenation checkpoint. Proc Natl Acad Sci USA. 2001; 98:1204412049. [PubMed: 11593014]

39. Zampetti-Bosseler F, Scott D. Cell death, chromosome damage and mitotic delay in normal human, ataxia telangiectasia and retinoblastoma fibroblasts after X-irradiation. Int J Radiat Biol Relat Stud Phys Chem Med. 1981; 39:547-558. [PubMed: 6972365]

40. Paules RS, Levedakou EN, Wilson SJ, Innes CL, Rhodes N, Tlsty TD, Galloway DA, Donehower LA, Tainsky MA, Kaufmann WK. Defective G2 checkpoint function in cells from individuals with familial cancer syndromes. Cancer Res. 1995; 55:1763-1773. [PubMed: 7712486]

41. Zhou BB, Chaturvedi P, Spring K, Scott SP, Johanson RA, Mishra R, Mattern MR, Winkler JD, Khanna KK. Caffeine abolishes the mammalian G(2)/M DNA damage checkpoint by inhibiting ataxia-telangiectasia-mutated kinase activity. J Biol Chem. 2000; 275:10342-10348. [PubMed: 10744722]

42. Cortez D. Caffeine inhibits checkpoint responses without inhibiting ATM and ATR. J Biol Chem. 2003; 278:37139-37145. [PubMed: 12847089]

43. Maher VM, Ouellette LM, Curren RD, McCormick JJ. Frequency of ultraviolet light-induced mutations is higher in xeroderma pigmentosum variant cells than in normal human cells. Nature. 1976; 261:593-595. [PubMed: 934300]

44. Myhr BC, Turnbull D, DiPaolo JA. Ultraviolet mutagenesis of normal and xeroderma pigmentosum variant human fibroblasts. Mutat Res. 1979; 62:341-353. [PubMed: 503099]

45. Lehmann AR. Postreplication repair of DNA in UV-irradiated mammalian cells. Basic Life Sci. 1975; 5B:617-623. [PubMed: 1191182]

46. Lehmann AR. The relationship between pyrimidine dimers and replicating DNA in UV-irradiated human fibroblasts. Nucleic Acids Res. 1979; 7:1901-1912. [PubMed: 231765]

47. Lehmann AR, Kirk-Bell S, Arlett CF, Paterson MC, Lohman PH, de Weerd-Kastelein EA, Bootsma D. Xeroderma pigmentosum cells with normal levels of excision repair have a defect in DNA synthesis after UV-irradiation. Proc Natl Acad Sci USA. 1975; 72:219-223. [PubMed: 1054497]

48. Fujiwara Y, Tatsumi M. Replicative bypass repair of ultraviolet damage to DNA of mammalian cells: caffeine sensitive and caffeine resistant mechanisms. Mutat Res. 1976; 37:91-110. [PubMed: 967189]

49. Laposa RR, Feeney L, Cleaver JE. Recapitulation of the cellular xeroderma pigmentosum-variant phenotypes using short interfering RNA for DNA polymerase H. Cancer Res. 2003; 63:39093912. [PubMed: 12873983] 
50. Kastan MB, Onyekwere O, Sidransky D, Vogelstein B, Craig RW. Participation of p53 protein in the cellular response to DNA damage. Cancer Res. 1991; 51:6304-6311. [PubMed: 1933891]

51. Kastan MB, Onyekwere O, Sidransky D, Volgelstein B, Craig R. Participation of p53 protein in the cellular responses to DNA damage. Cancer Res. 1991; 51:6304-6311. [PubMed: 1933891]

52. Falck J, Mailand N, Syljuasen RG, Bartek J, Lukas J. The ATM-Chk2-Cdc25A checkpoint pathway guards against radioresistant DNA synthesis. Nature. 2001; 410:842-847. [PubMed: 11298456]

53. Peng CY, Graves PR, Thoma RS, Wu Z, Shaw AS, Piwnica-Worms H. Mitotic and G2 checkpoint control: regulation of 14-3-3 protein binding by phosphorylation of Cdc25C on serine-216. Science. 1997; 277:1501-1505. [PubMed: 9278512]

54. Donzelli M, Draetta GF. Regulating mammalian checkpoints through Cdc25 inactivation. EMBO Rep. 2003; 4:671-677. [PubMed: 12835754]

55. Blasina A, de Weyer IV, Laus MC, Luyten WH, Parker AE, McGowan CH. A human homologue of the checkpoint kinase Cds1 directly inhibits Cdc25 phosphatase. Curr Biol. 1999; 9:1-10. [PubMed: 9889122]

56. Jin P, Hardy S, Morgan DO. Nuclear localization of cyclin B1 controls mitotic entry after DNA damage. J Cell Biol. 1998; 141:875-885. [PubMed: 9585407]

57. Toyoshima F, Moriguchi T, Wada A, Fukuda M, Nishida E. Nuclear export of cyclin B1 and its possible role in the DNA damage-induced G2 checkpoint. Embo J. 1998; 17:2728-2735. [PubMed: 9582266]

58. Hagting A, Karlsson C, Clute P, Jackman M, Pines J. MPF localization is controlled by nuclear export. Embo J. 1998; 17:4127-4138. [PubMed: 9670027]

59. Toyoshima-Morimoto F, Taniguchi E, Shinya N, Iwamatsu A, Nishida E. Polo-like kinase 1 phosphorylates cyclin B1 and targets it to the nucleus during prophase. Nature. 2001; 410:215220. [PubMed: 11242082]

60. Smits VA, Klompmaker R, Arnaud L, Rijksen G, Nigg EA, Medema RH. Polo-like kinase-1 is a target of the DNA damage checkpoint. Nat Cell Biol. 2000; 2:672-676. [PubMed: 10980711]

61. van Vugt MA, Smits VA, Klompmaker R, Medema RH. Inhibition of Polo-like kinase-1 by DNA damage occurs in an ATM- or ATR-dependent fashion. J Biol Chem. 2001; 276:41656-41660. [PubMed: 11514540]

62. Deming PB, Flores KG, Downes CS, Paules RS, Kaufmann WK. ATR enforces the topoisomerase II-dependent G2 checkpoint through inhibition of Plk1 kinase. J Biol Chem. 2002; 277:36832 36838. [PubMed: 12147700]

63. Tercero JA, Diffley JF. Regulation of DNA replication fork progression through damaged DNA by the Mec1/Rad53 checkpoint. Nature. 2001; 412:553-557. [PubMed: 11484057]

64. Beetham KL, Busse PM, Tolmach LJ. Synergistic killing of HeLa cells by hydroxyurea and caffeine. J Cell Physiol. 1983; 115:283-290. [PubMed: 6853607]

65. Pardee AB, James LJ. Selective killing of transformed baby hamster kidney (BHK) cells. Proc Natl Acad Sci USA. 1975; 72:4994-4998. [PubMed: 174089]

66. O'Neill FJ. Differential effects of cytochalasin B and caffeine on control of DNA synthesis in normal and transformed cells. J Cell Physiol. 1979; 101:201-217. [PubMed: 511951]

67. Beetham KL, Tolmach LJ. Growth and death of HeLa cells in the presence of caffeine. J Cell Physiol. 1982; 113:385-397. [PubMed: 7174739] 


\section{A. F1-hTERT}
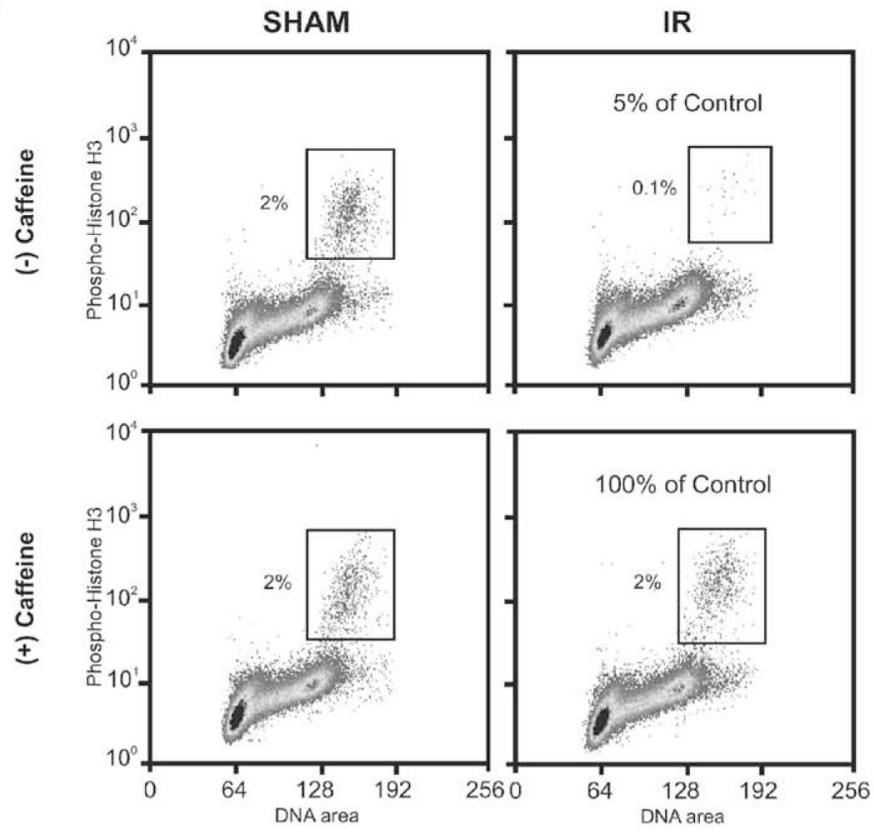

B. AT-hTERT
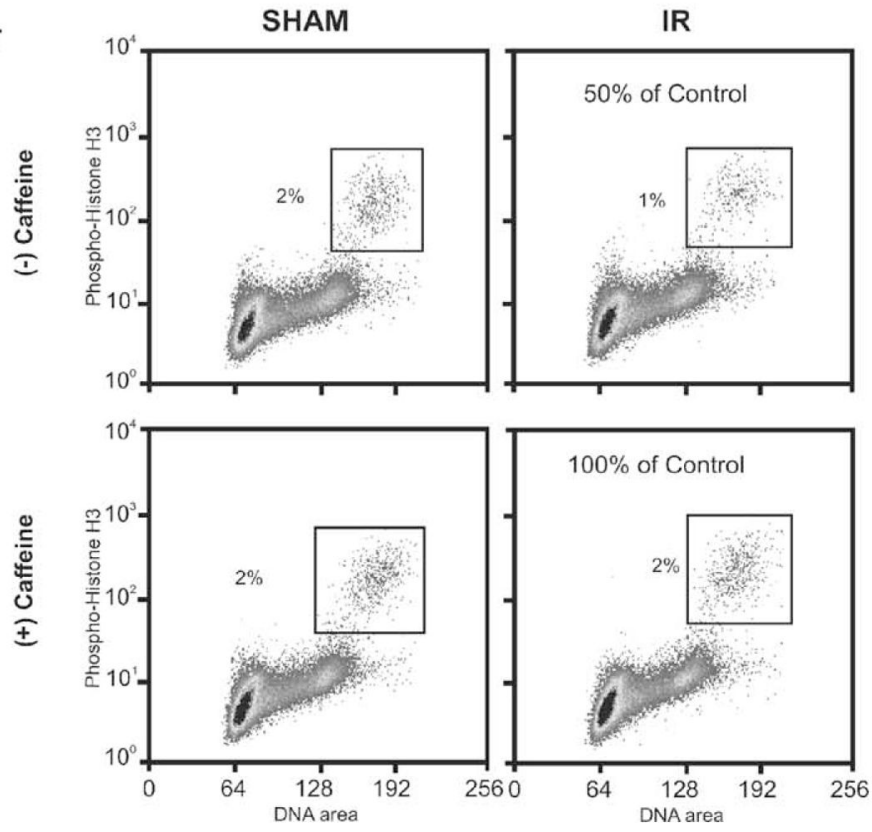

Fig. 1.

Caffeine inhibits G2 checkpoint function. Logarithmically growing F1-hTERT (A) and AThTERT (B) fibroblasts were pretreated with $2 \mathrm{mM}$ caffeine for $30 \mathrm{~min}$ prior to either being sham-treated or irradiated with $1.5 \mathrm{~Gy}$. Two hours post-IR the cells were harvested and processed as described in Section 2 for determination of mitotic index. Propidium iodide was used to stain DNA ( $X$-axis) and an antibody specific for phosphohistone $\mathrm{H} 3$ was used to stain mitotic cells ( $Y$-axis).

Mutat Res. Author manuscript; available in PMC 2014 June 05. 


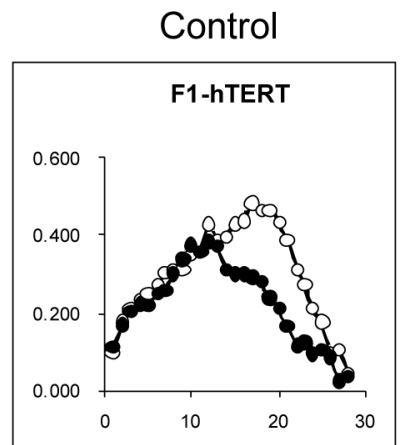

Caffeine

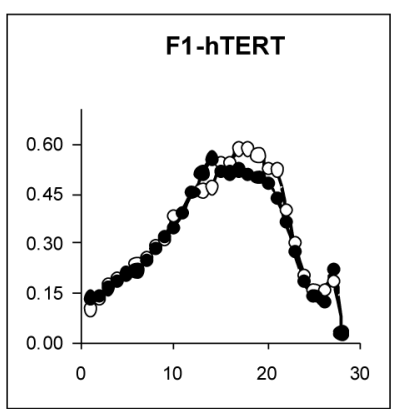

IR
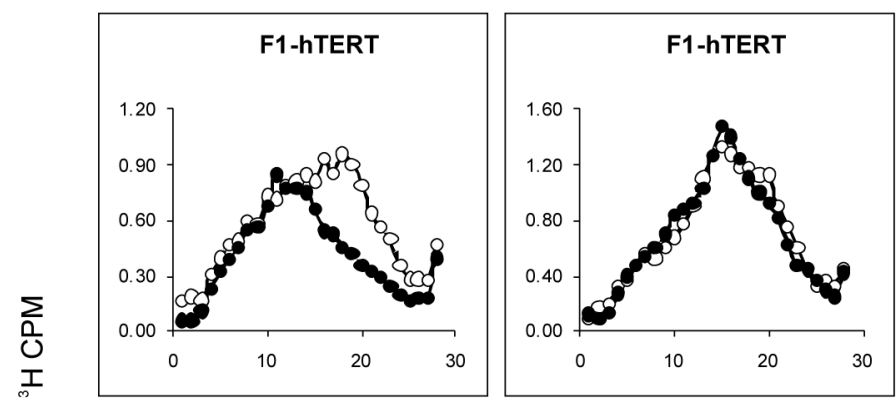

\section{UVC}
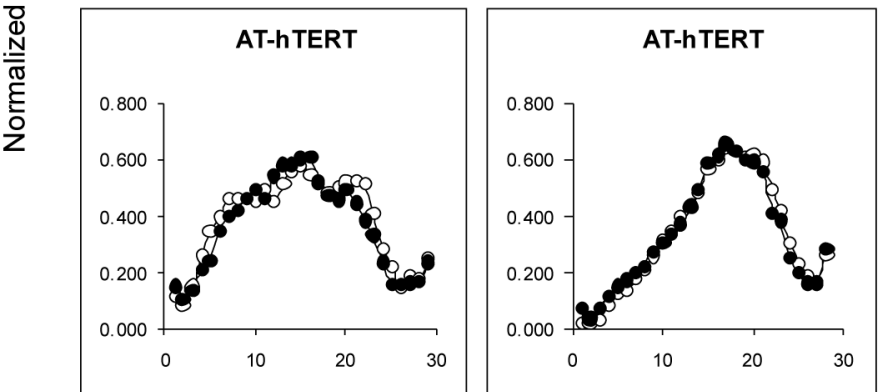

IR
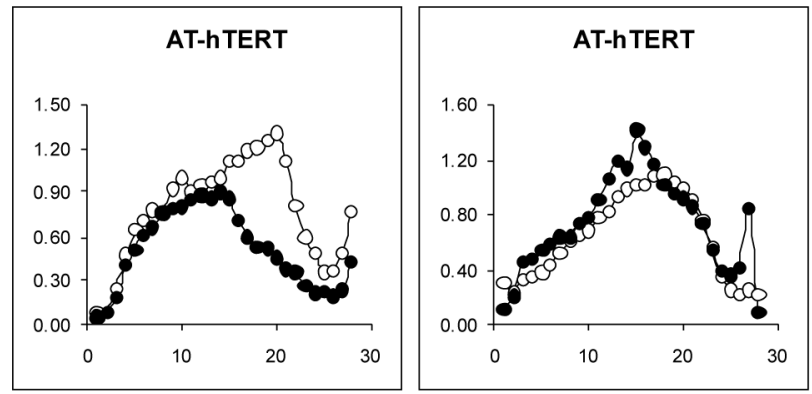

UVC

Fraction Number

Fig. 2.

Caffeine abrogates the ATM- and ATR-dependent S checkpoints. F1-hTERT and AT-

hTERT fibroblasts were uniformly labeled with $\left[{ }^{14} \mathrm{C}\right]$ thymidine as described and incubated for $30 \mathrm{~min}$ in medium alone or medium containing $2 \mathrm{mM}$ caffeine. Cells were sham-treated or irradiated with $1 \mathrm{~J} / \mathrm{m}^{2} \mathrm{UVC}$ or $1.5 \mathrm{~Gy} \mathrm{IR}$, incubated in reserved medium for $30 \mathrm{~min}$ and then pulse-labeled with $\left[{ }^{3} \mathrm{H}\right]$ thymidine for $15 \mathrm{~min}$. Cells were harvested and nascent DNA separated by velocity sedimentation (see Section 2 ). Net ${ }^{3} \mathrm{H}$ radioactivity corrected for ${ }^{14} \mathrm{C}$ spillover was normalized to cell number (total ${ }^{14} \mathrm{C}$ radioactivity). Open circles: sham-treated 
cells; closed circles: irradiated cells. The UVC profiles illustrated in this figure have been previously published [25]. 


\section{A. F1-hTERT}

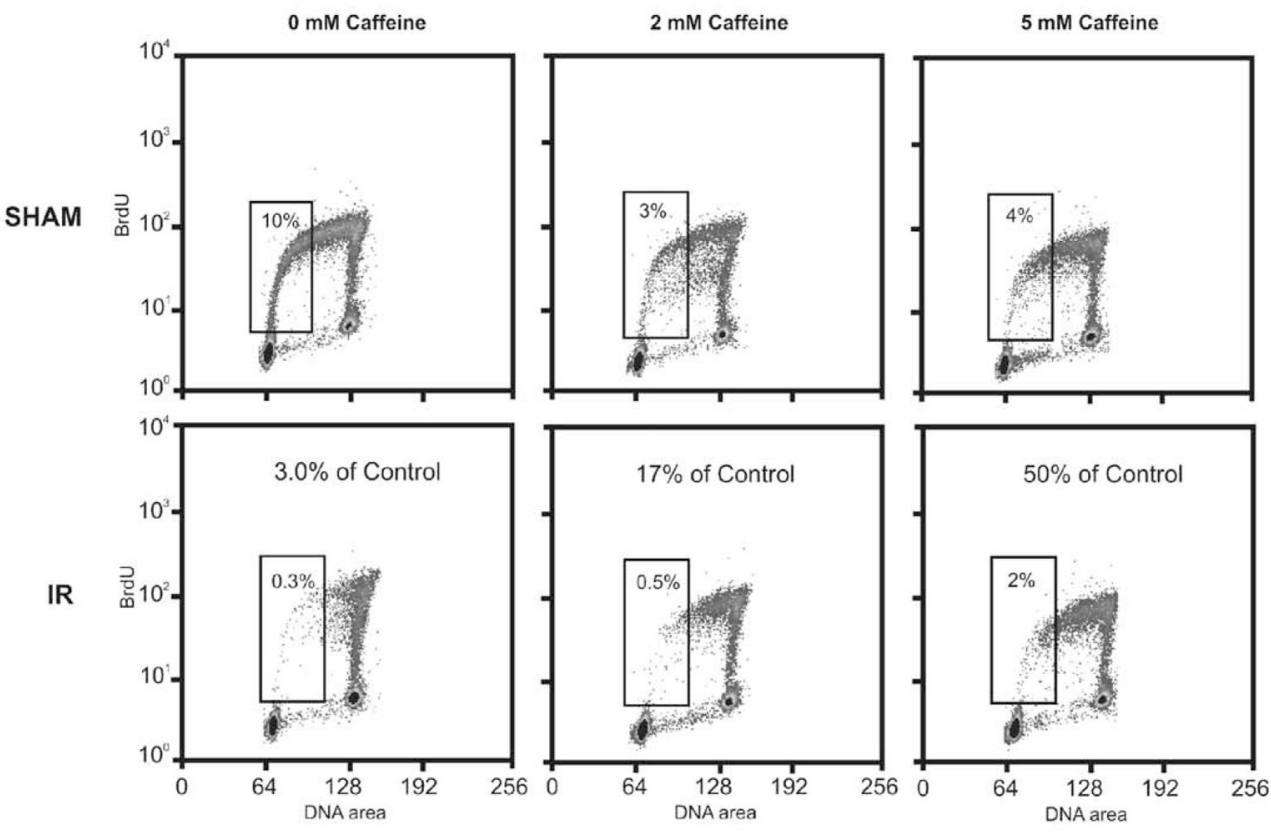

\section{B. AT-hTERT}
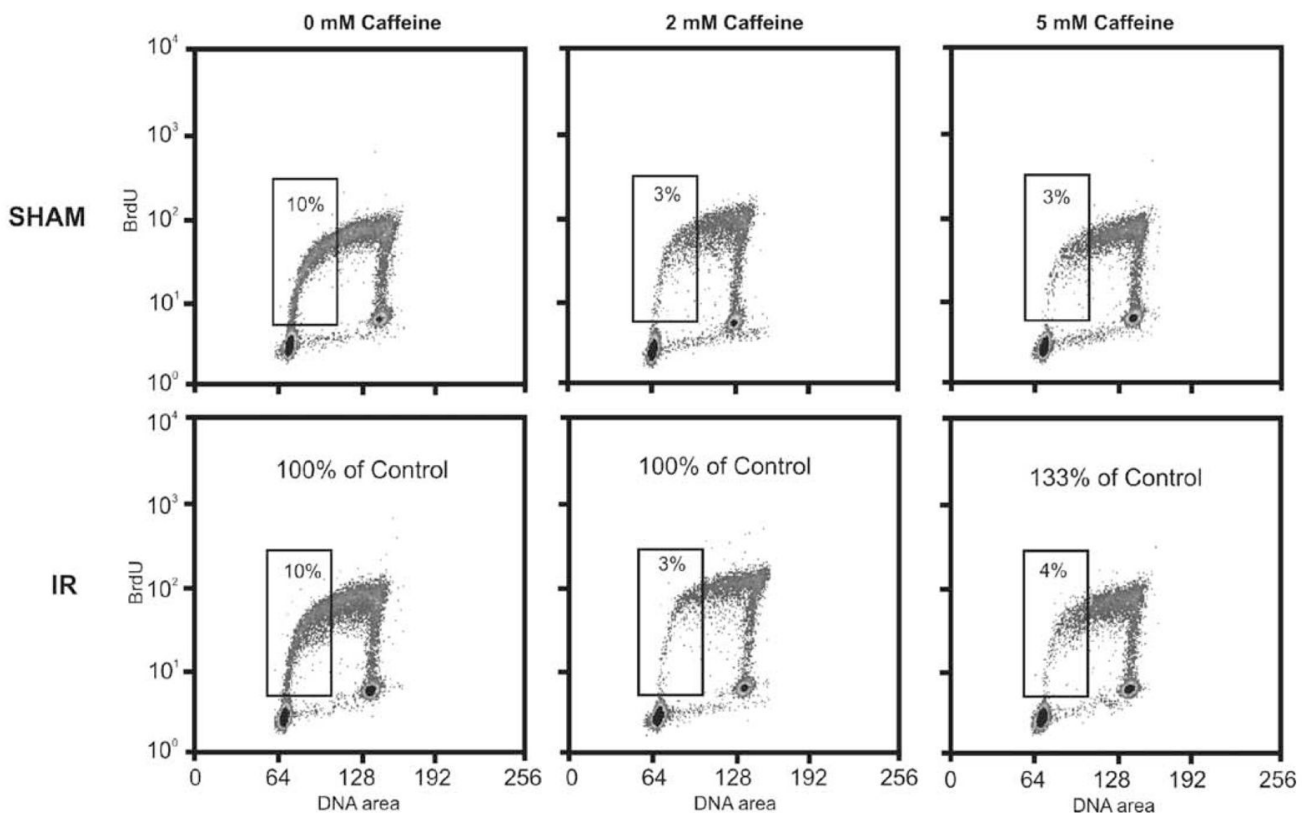

Fig. 3.

Caffeine does not inhibit G1 checkpoint function but induces a G1 delay. Logarithmically growing F1-hTERT (A) and AT-hTERT (B) fibroblasts were pretreated with 0,2 , or $5 \mathrm{mM}$ caffeine for $30 \mathrm{~min}$ prior to being sham-treated or irradiated with $1.5 \mathrm{~Gy}$. Cells were incubated for $6 \mathrm{~h}$ and then pulsed with $10 \mathrm{mM}$ BrdU for $2 \mathrm{~h}$. Cells were harvested and analyzed for G1 checkpoint function by flow cytometry as described in Section 2.

Propidium iodide was used to stain for DNA content ( $X$-axis) and anti-BrdU-FITC to stain BrdU-labeled cells ( $Y$-axis). Numbers within the boxes represent the fraction of total cells in 
the first half of S phase. The indicated percent of control was calculated from the matched sham profile (non-irradiated profile from cells incubated in the same concentration of caffeine). 

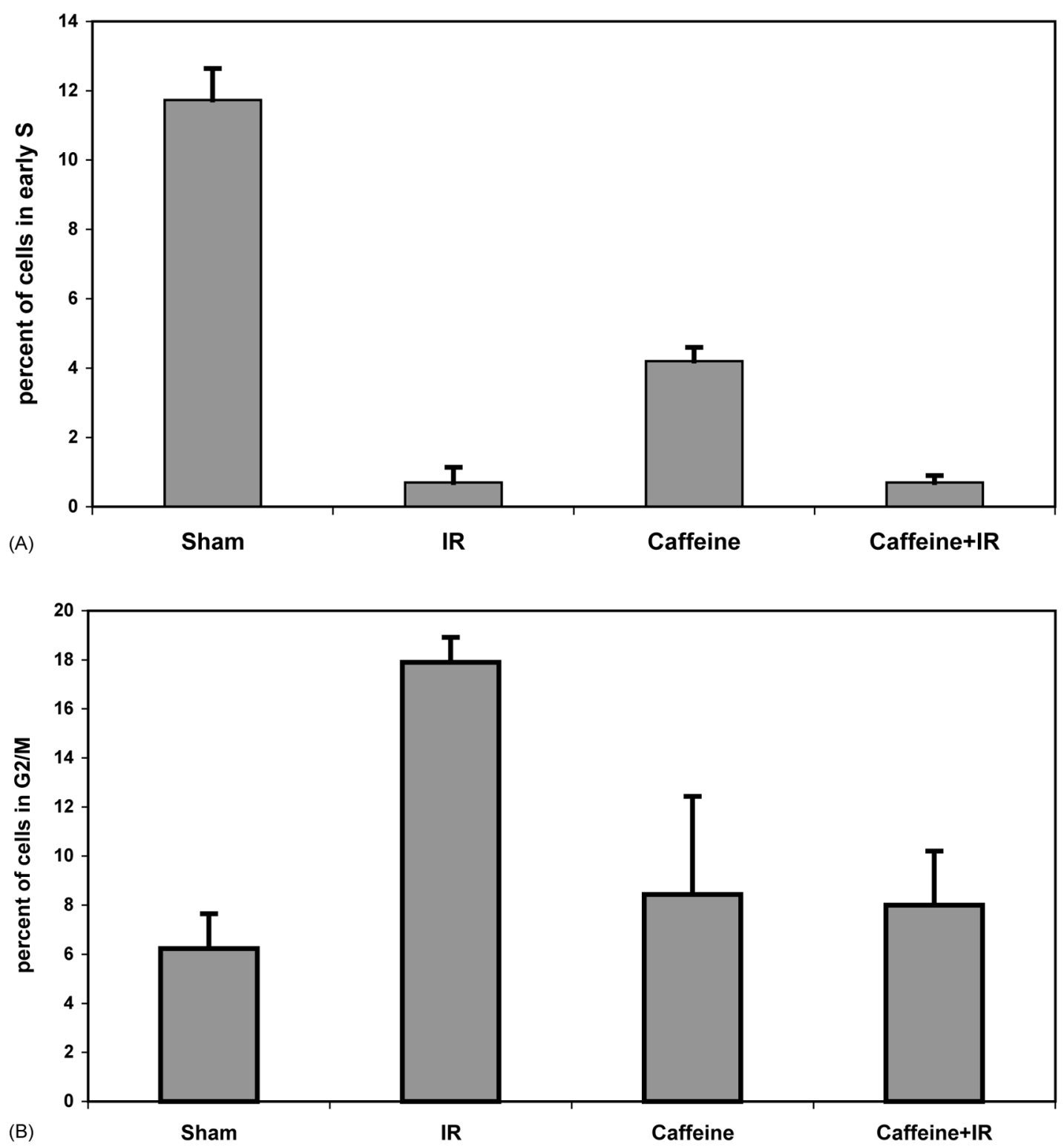

Fig. 4.

Caffeine reverses IR-induced G2 delay but not G1 arrest. The effect of IR and caffeine (2 $\mathrm{mM}$ ) on $\mathrm{G} 1$ and $\mathrm{G} 2$ checkpoint function in F1-hTERT fibroblasts was determined by flow cytometric studies as illustrated in Fig. 3. Results from several experiments were graphed as the average percent of cells in early $S$ phase (A) or the percentage of cells in G2/M (B) (mean \pm S.D., $n=3$ ). 


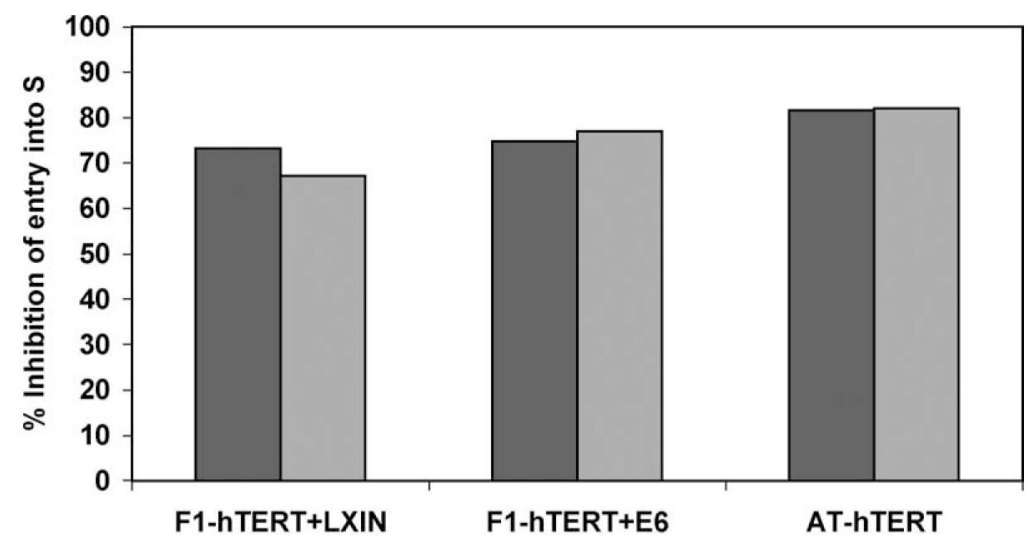

(A)

$\square 2 \mathrm{mM}$ Caffeine $\square 5 \mathrm{mM}$ Caffeine

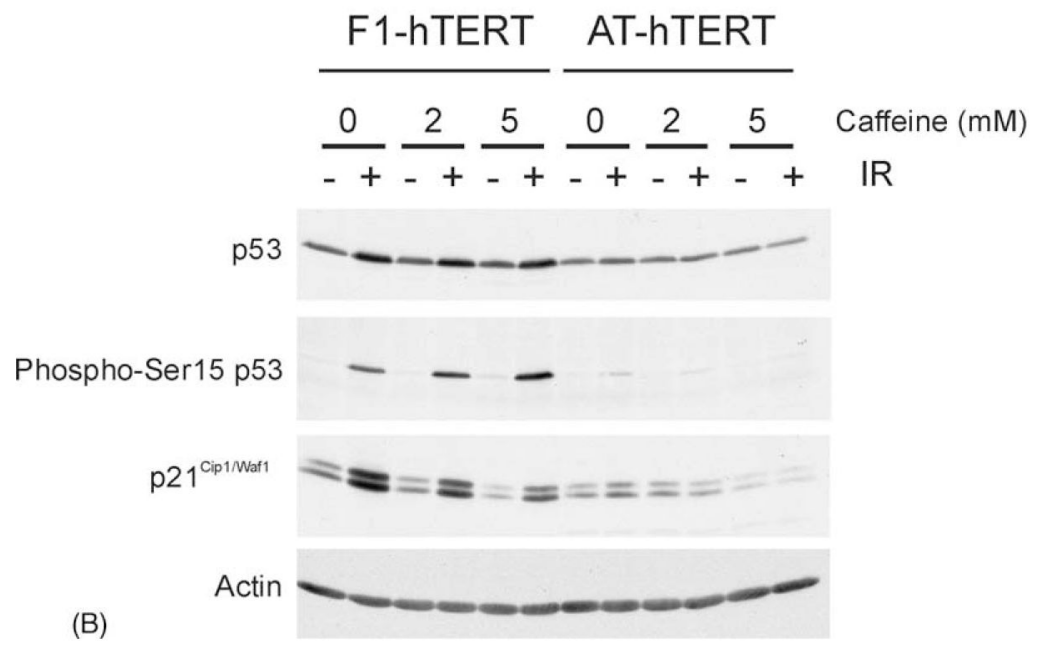

Fig. 5.

Caffeine-induced G1 delay is independent of p53. (A) Logarithmically growing F1-hTERTLXIN, F1-hTERT-E6, and AT-hTERT fibroblasts were treated with either 0, 2, or $5 \mathrm{mM}$ caffeine for $6 \mathrm{~h}$ and then pulsed with BrdU for an additional $2 \mathrm{~h}$. Cells were harvested and the effect of caffeine on $\mathrm{S}$ phase entry analyzed by flow cytometry as described in the legend to Fig. 3. In this graph, the $Y$-axis shows the percent inhibition of entry of cells into early $S$ by caffeine. The results shown represent the average of two experiments. (B) F1hTERT and AT-hTERT fibroblasts were incubated for $30 \mathrm{~min}$ in medium alone or medium containing $2 \mathrm{mM}$ caffeine and then either sham-treated or irradiated with $1.5 \mathrm{~Gy}$ IR. Cells were incubated for $6 \mathrm{~h}$ and then harvested. Protein extracts were prepared and $100 \mu \mathrm{g}$ of total protein analyzed by western immunoblot analysis. 

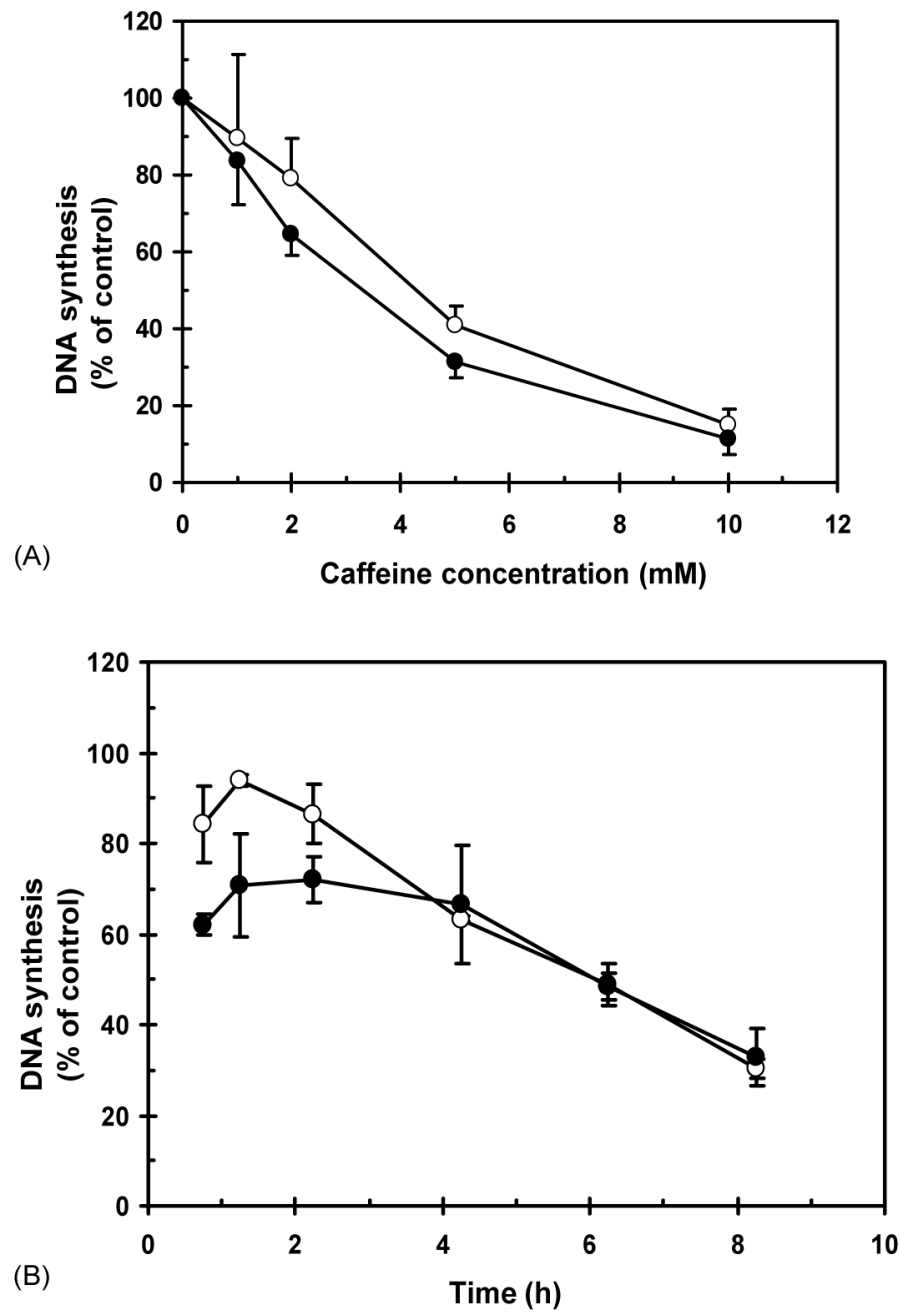

Fig. 6.

Caffeine inhibits DNA synthesis. F1-hTERT and AT-hTERT fibroblasts were grown in the presence of $\left[{ }^{14} \mathrm{C}\right]$ thymidine for $\sim 40 \mathrm{~h}$ to label DNA uniformly, and then in non-radioactive medium for $\geq 3 \mathrm{~h}$. (A) Cells were treated with $0,1,2,5$, or $10 \mathrm{mM}$ caffeine, incubated at 37 ${ }^{\circ} \mathrm{C}$ for $30 \mathrm{~min}$, and then labeled for $15 \mathrm{~min}$ in medium containing $\left[{ }^{3} \mathrm{H}\right]$ thymidine. (B) In time course studies, cells were treated with 0 or $2 \mathrm{mM}$ caffeine for $0.5,1,2,4,6$, or $8 \mathrm{~h}$ and then labeled for $15 \mathrm{~min}$ in medium containing $\left[{ }^{3} \mathrm{H}\right.$ ] thymidine. Net ${ }^{3} \mathrm{H}$ radioactivity corrected for ${ }^{14} \mathrm{C}$ spillover was normalized to cell number (total ${ }^{14} \mathrm{C}$ radioactivity). Normalized ${ }^{3} \mathrm{H}$ CPM was graphed as a percent of sham controls. Open circles: F1-hTERT; closed circles: AT-hTERT. 

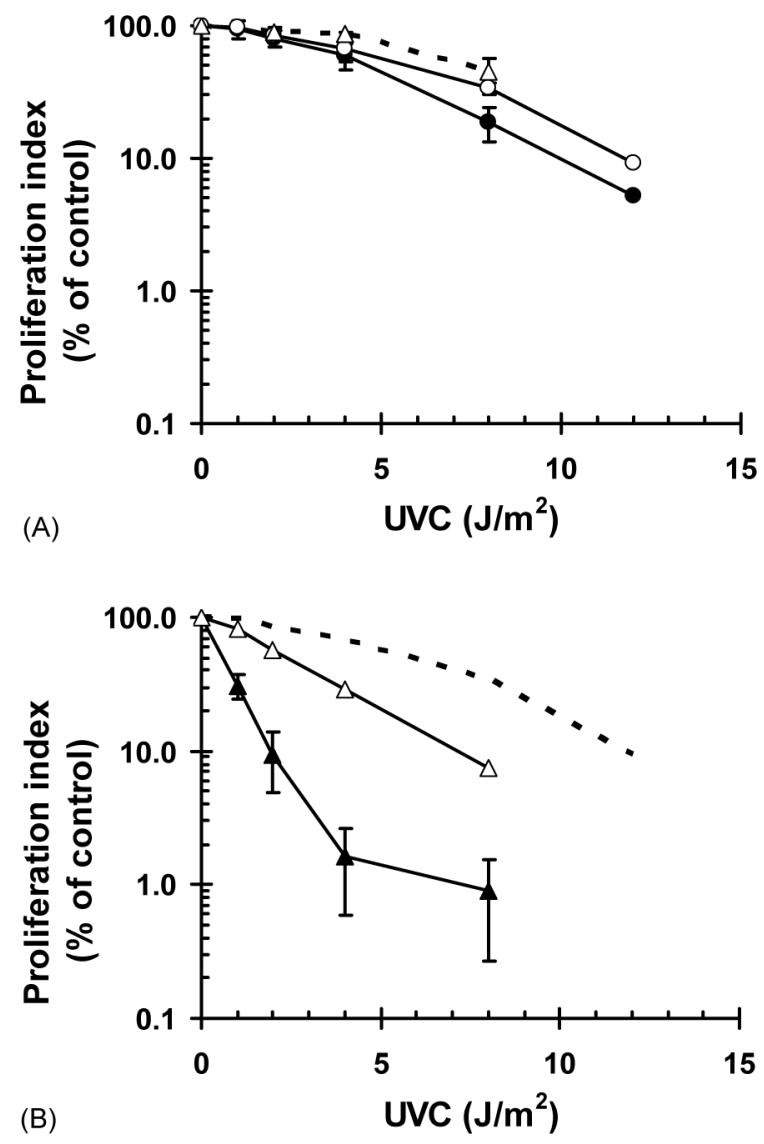

Fig. 7.

Caffeine enhances UVC-induced cytotoxicity. Log cultures of F1-hTERT (A) and CRL1162-hTERT (B) were irradiated with the indicated fluences of UVC and then incubated for $72 \mathrm{~h}$ in medium containing either 0 or $1 \mathrm{mM}$ caffeine. Cells were pulse labeled with $1 \mathrm{mCi} / \mathrm{ml}\left[{ }^{3} \mathrm{H}\right]$ thymidine for $1 \mathrm{~h}$, and acid-insoluble DNA collected on microfibre filters. $\left[{ }^{3} \mathrm{H}\right]$ thymidine incorporation was graphed as a percent of sham controls. (A) F1hTERT grown in the absence (open circles) or the presence (closed circles) of $1 \mathrm{mM}$ caffeine following exposure to UVC; dashed line with open triangles represents the colonyforming efficiency of F1-hTERT in the absence of caffeine. (B) CRL1162-hTERT grown in the absence (open triangles) or the presence (closed triangles) of $1 \mathrm{mM}$ caffeine after irradiation; the dashed line represents the results with F1-hTERT grown in the absence of caffeine (open circles in A). 

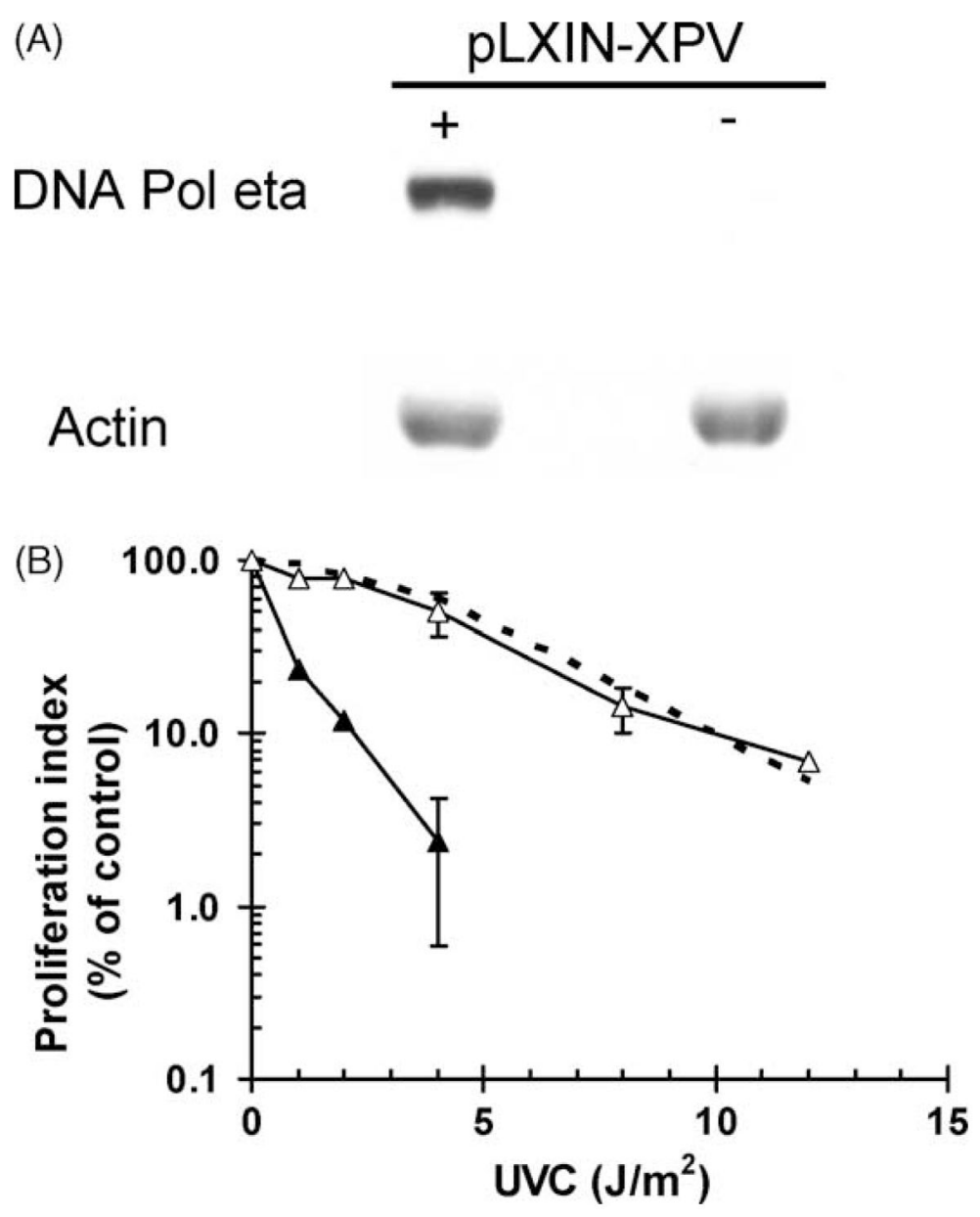

Fig. 8.

DNA pol eta suppresses the enhancement of UVC cytotoxicity by caffeine. (A) Log cultures of CRL1162-pLXIN (-) and CRL1162-pLXIN-XPV (+) fibroblasts were harvested and whole cell extracts were prepared. Protein $(50 \mu \mathrm{g})$ was separated on an $8 \%$ SDS-PAGE and then probed with specific antibodies against DNA pol $\eta$ and actin. (B) Log cultures of CRL1162-pLXIN (closed triangles), CRL1162-hTERT-XPV (open triangles), and F1hTERT (dashed line) fibroblasts were irradiated with indicated fluences of UVC and incubated for $72 \mathrm{~h}$ in medium containing $1 \mathrm{mM}$ caffeine. The degree of cytotoxicity was determined as described in the legend to Fig. 7. The dashed line represents the results observed with F1-hTERT in the presence of caffeine (Fig. 7A, closed circles). 